Original Research Paper

\title{
Status of Heavy Metals in Water and Sediment of the Meghna River, Bangladesh
}

\author{
${ }^{1}$ Mahmud Hassan, ${ }^{1}$ Mirza A.T.M. Tanvir Rahman, ${ }^{2}$ Badhan Saha and ${ }^{1}$ Abdul Kadir Ibne Kamal \\ ${ }^{I}$ Department of Environmental Sciences, Jahangirnagar University, Dhaka-1342, Bangladesh \\ ${ }^{2}$ Soil, Agronomy and Environment Section, Biological Research Division, BCSIR Laboratories, Dhaka- 1205, Bangladesh
}

Article history

Received: 06-06-2015

Revised: $14-08-2015$

Accepted: 17-11-2015

Corresponding Author:

Mirza A.T.M. Tanvir Rahman

Department of Environmental

Sciences, Jahangirnagar University,

Dhaka-1342, Bangladesh

Tel: +8801914019163

Email: tanvir497@juniv.edu

\begin{abstract}
The pollution of river water and sediments by heavy metals has assumed serious problems due to their toxicity and accumulative behavior. The present study has been undertaken to assess the levels of heavy metals and the extent of pollution in the surface water and sediments from the Meghna river. Water and sediment samples were collected by the Standard Methods and, processed and analyzed for heavy metals using Flame Atomic Absorption Spectrophotometer (FAAS). The mean concentrations of heavy metal found in the river water were in the order of: $\mathrm{Fe}\left(1.0224 \mathrm{mg} \mathrm{L}^{-1}\right)>\mathrm{Zn}\left(0.0364 \mathrm{mg} \mathrm{L}^{-1}\right)>\mathrm{Cr}\left(0.0346 \mathrm{mg} \mathrm{L}^{-1}\right)$ $>\operatorname{Mn}\left(0.0088 \mathrm{mg} \mathrm{L}^{-1}\right)>\mathrm{Cd}\left(0.003 \mathrm{mg} \mathrm{L}^{-1}\right)$ and in the sediments in the order of: $\mathrm{Fe}\left(1281.416 \mathrm{mg} \mathrm{kg}^{-1}\right)>\mathrm{Mn}\left(442.596 \mathrm{mg} \mathrm{kg}^{-1}\right)>\mathrm{Zn}(79.021$ $\left.\mathrm{mg} \mathrm{kg}{ }^{-1}\right)>\mathrm{Ni}\left(76.116 \mathrm{mg} \mathrm{kg}^{-1}\right)>\mathrm{Cr}\left(31.739 \mathrm{mg} \mathrm{kg}^{-1}\right)>\mathrm{Pb}(9.4702 \mathrm{mg}$ $\left.\mathrm{kg}^{-1}\right)>\mathrm{Cd}\left(0.230 \mathrm{mg} \mathrm{kg}^{-1}\right)$. Pb and Ni were found below detection limit in river water. Based on the findings, the Meghna river water can be considered as unpolluted with respect to $\mathrm{Cd}, \mathrm{Cr}, \mathrm{Mn}$ and $\mathrm{Zn}$, whereas concentration of $\mathrm{Fe}$ was above the standard value according to recommended standard guidelines. According to Sediment Quality Guideline (USEPA, 1989), sediments were not polluted for $\mathrm{Cd}, \mathrm{Pb}$ and $\mathrm{Zn}$; moderately polluted for $\mathrm{Cr}$ and $\mathrm{Mn}$ and heavily polluted for Ni. The sediment geo-accumulation index $\left(\mathrm{I}_{\mathrm{geo}}\right)$ values showed no pollution for most of sampling sites for all studied heavy metals. Pollution Load Index (PLI) values showed that all the studied sampling sites were not polluted and on the other hand mean Contamination Factor (CF) values showed low pollution for all measured heavy metals except $\mathrm{Ni}$ which indicated moderate pollution. This study can be used as reference to monitor the quality of water and sediments of the Meghna river.
\end{abstract}

Keywords: Contamination Factor, Geo-Accumulation Index, Pollution Load Index, Sediment Quality, Water Quality

\section{Introduction}

Rapid urbanization and industrial development during last decade have provoked some serious concerns in environment. Heavy metal contamination in river is one of the major quality issues in developing countries (Silambarasan et al., 2012). rivers are a dominant pathway for metals transport (Mohiuddin et al., 2010) and metals enter these aquatic systems mainly through natural inputs such as weathering and erosion of rocks and anthropogenic sources including urban, industrial and agricultural activities, terrestrial runoff and sewage disposal (Barakat et al., 2012). As industrial activities, domestic wastes, urbanization and land development all contribute to the heavy metal pollution of rivers. The identification and quantification of the heavy metal in water and sediments are important environmental issues (Manoj et al., 2012). Contamination of aquatic ecosystems with heavy metals has received much attention due to their toxicity, abundance and persistence in the environment and subsequent accumulation in aquatic habitats (Arnason and Fletcher, 2003). Heavy metals entering natural water become part of the watersediment system and their distribution processes are 
controlled by a dynamic set of physical-chemical equilibria. The metal solubility is principally controlled by $\mathrm{pH}$, concentration and type of ligands and chelating agents, oxidation-state of mineral components and the redox environment of the system. Since each form may have different bioavailability and toxicity, the environmentalists are rightly concerned about the exact forms of metal present in the aquatic environment. Thus distribution of heavy metals in water and sediments play a key role in detecting sources of heavy metal pollution in aquatic ecosystem (Singh et al., 2012). Their accumulation and distribution in sediments, water and environment are increasing at an alarming rate causing deposition and sedimentation in water reservoirs and affecting aquatic organisms as well (Mohiuddin et al., 2011). The contamination of surface water by heavy metals is a serious ecological problem as some of them are toxic even at low concentrations, are non-degradable and can bio-accumulate through food chain (Abdullah, 2013). Heavy metals undergo a global ecological cycle in which natural water are the main pathways (Saha and Hossain, 2011). Sediments act as sink of heavy metals can become immediate source of metal pollution of the water bodies (Manoj et al., 2012). Data from sediments can provide information on the impact of distant human activity on the wider ecosystem. The composition of sediment sequences provides the best natural archives of recent environmental changes. It acts as both carrier and potential sources of contaminants in an aquatic environment and can serve as a pool that can retain or release contaminants to the water column by various processes of remobilization (Ogbeibu et al., 2014). Heavy metals accumulate in the sediments through complex physical and chemical adsorption mechanisms depending on the nature of the sediment matrix and the properties of the adsorbed compounds (Rabee et al., 2011). Exposure to heavy metals has linked to several human diseases such as development retardation or malformation, kidney damage, cancer, abortion, effect on intelligence and behavior and even death in some cases of exposure to very high concentrations. The most toxic heavy metals $\mathrm{Cr}, \mathrm{Ni}, \mathrm{Pb}, \mathrm{Cd}$ and $\mathrm{As}$. $\mathrm{Cr}$ (VI), Ni and $\mathrm{Cd}$ are carcinogenic; $\mathrm{As}$ and $\mathrm{Cd}$ are teratogenic and the health effects of $\mathrm{Pb}$ include neurological impairment and malfunctioning of the central nervous system. Although some heavy metals such as Fe, Mn, Co, Cu and $\mathrm{Zn}$ are essential micronutrients for fauna and flora, they are dangerous at high levels (Saha and Hossain, 2011; Moore et al., 2009).

Bangladesh is constituted by a large delta at the confluence of three major rivers of the world, the Ganges, the Brahmaputra and the Meghna (Alam, 2003). The Meghna river is polluting at different sites from industries which situated on the banks of this river or very close to the river system. One of the most polluted sites of the Meghna river is the Meghna Ghat and its adjacent area. The dominant industries in this area are shipyard, cement, paper, jute, super board, oil, sugar, food processing, salt and chemical industries. The river receives industrial wastes water directly from industries and also domestic and agro-chemical wastes which contribute heavy metal pollution in water and sediment. But no significant studies have been undertaken to investigate the pollution of the Meghna river. So it is necessary to assess the state of the water and sediment quality of the Meghna river. The objective of the present study is to assess the level of heavy metal concentrations in water and sediment that will focus on the pollution status of the Meghna river.

\section{Materials and Methods}

\section{Study Area}

The Ganges-Brahmaputra-Meghna (G-B-M) drainage basin occupies the total Bengal Basin, which is one of the unique basins of the world (Datta and Subramanian, 1998). These three river basins cover about $1.75 \times 10^{6} \mathrm{~km}^{2}$ across five different countriesChina, Nepal, India, Bhutan and Bangladesh (Mirza et al., 1998). The Meghna river is the main outlet of the Ganges-Brahmaputra river system collecting water from a vast catchments area of these countries. The total catchment area of the Meghna river is $82000 \mathrm{~km}^{2}$ and 13 million tons of sediment is being transported per year (Rahman, 2013). The precipitation, evaporation and discharge of water at different seasons of the Meghnariver are given in Table 1. The Meghna Ghat and adjacent area in Narayangonj and Munshigonj districts had been chosen in order to assess the surface water and sediment samples on both banks of the river. A total of eleven sampling sites were selected depending upon the presumed water and sediment quality and extent of pollution by visiting the study area before sample collection (Fig. 1).

Table 1. Precipitation, evaporation and discharge of water at different seasons of the Meghna river (Uddin et al., 2014)

\begin{tabular}{lccc} 
& Pre-monsoon & Monsoon & Post-monsoon \\
& $10^{6} \mathrm{~m}^{3} /$ day & $10^{6} \mathrm{~m}^{3} /$ day & 16.736 \\
\hline Precipitation & 83.524 & 230.755 & 52.774 \\
Evaporation & 34.261 & 44.688 & 1556.367 \\
Discharge & 6.472 & 4399.357 & 1557 \\
\hline
\end{tabular}




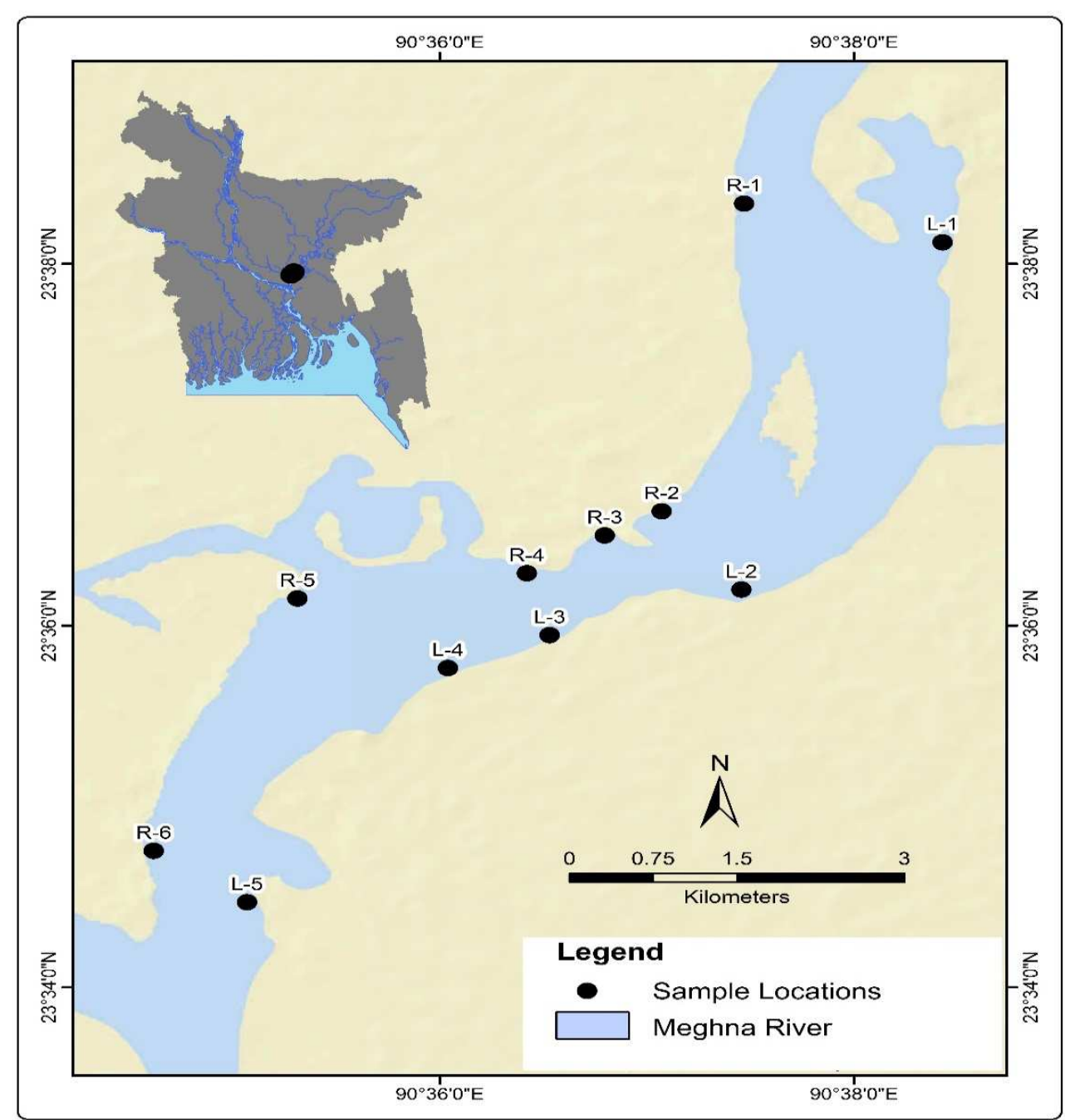

Fig. 1. Study area and sampling sites (Right and Left bank denoted as R and L, respectively)

\section{Sample Collection and Preparation}

Eleven water and 11 sediments samples were collected on 6 August, 2014 from the selected sampling sites. Surface water samples were collected from 15-30 $\mathrm{cm}$ below the river water surface and at distances of 40$80 \mathrm{~cm}$ from the bank of the river in pre-labeled sample bottles which was washed with $10 \% \mathrm{HNO}_{3}$ acid and rinsed repeatedly with distilled water. Before the sample collection, sample bottles were rinsed three times with the river water (Tareq et al., 2013). For measurement of heavy metal concentration, $65 \%$ concentrated $\mathrm{HNO}_{3}$ acid was added to each sample immediately to bring the $\mathrm{pH}$ blow 2 to minimize precipitation and adsorption onto container walls (APHA, 1998). Sediment samples were taken at a depth of $0-10 \mathrm{~cm}$ and then immediately transferred into polyethylene bags. Prior to sampling the polyethylene were washed with $10 \% \mathrm{HNO}_{3}$ acid solution and ringed with distilled water (Manoj et al., 2012; Rabee et al., 2011; Ogbeibu et al., 2014). Water and sediments samples were transported using ice box to the laboratory and water samples were properly labeled and preserved in refrigerator at $4{ }^{\circ} \mathrm{C}$ temperature. Sediment samples were dried in a dry and dust-free place at room temperature, ground into fine powder using pestle and mortar before sieved under $2 \mathrm{~mm}$ mesh. The samples were then stored in plastic container (Jumbe and Nandini, 2009).

\section{Physico-chemical Analysis of river Water and Sediment}

Eight physico-chemical parameters of water samples were measured by using different instruments and methods. A centigrade thermometer was used for the measurement of temperature. $\mathrm{pH}$, TDS and EC were measured by portable multiparameter meter 
(Model: Sense Ion, 156; HACH, USA). Turbidity and DO were measured by portable turbidity meter (Model: 93703; Hanna Instruments, Hungary) and digital DO meter (Model: HQ 30 D; HACH, USA), respectively. $\mathrm{BOD}$ was measured by $\mathrm{BOD}$ trak apparatus (Model: BODTrakII ${ }^{\mathrm{TM}}$; HACH, USA). COD was determined by titrimetric method according to Huq and Didarul-ul-Alam (2005). For sediment's pH measurement, $20 \mathrm{gm}$ sediment sample was taken into clean glass beaker and added $50 \mathrm{~mL}$ distilled water. The mixture was shaken on a shaking plate more than $30 \mathrm{~min}$ and then $\mathrm{pH}$ measured with portable multiparameter meter (Model: Sense Ion, 156; HACH, USA). Organic Matter (OM) was determined by wet oxidation method of Walkley and Black (1934).

\section{Estimation of Heavy Metals in Water and Sediment}

Water samples were digested with concentrated $\mathrm{HNO}_{3}$ acid as described by APHA (1998) and sediment samples were digested with concentrated $\mathrm{HNO}_{3}$ acid and concentrated $\mathrm{HClO}_{4}$ acid according to Huq and Didarul-ul-Alam (2005). Then the digested water and sediment samples were analyzed by Flame Atomic Absorption Spectrophotometer (Model: AA-7000; Shimadzu, Japan) for detection of heavy metals like $\mathrm{Cr}$, $\mathrm{Cd}, \mathrm{Pb}, \mathrm{Ni}, \mathrm{Fe}, \mathrm{Zn}$ and $\mathrm{Mn}$. The instrument was calibrated with chemical standard solutions in accordance with manufacturer's instructions.

\section{Sediment Quality Assessment}

\section{Geo-Accumulation Index (Igeo)}

The geo-accumulation index $\left(\mathrm{I}_{\text {geo }}\right)$ has been widely used in trace metal studies since the late 1960s (Yaqin et al., 2008). It has been successfully applied to the measurement of bottom sediments contamination (Loska et al., 2003). The $\mathrm{I}_{\text {geo }}$ enables the assessment of metal contamination in sediments by comparing current concentrations with pre-industrial levels (Qingjie and Jun, 2008). $\mathrm{I}_{\text {geo }}$ is calculated using the following formula (Müller, 1969):

$$
I_{\text {geo }}=\log (C n / 1.5 \times B n)
$$

where, $\mathrm{Cn}$ is the measured concentration of the metal $(n)$ in the sediment and $B n$ is the geochemical background of the metal $(n)$. The factor 1.5 is used for the possible variations of the background data due to lithological variations. Average shale standard for different metals reported by Turekian and Wedepohl (1961) was taken as background concentration throughout the study. Müller (1981) classified $I_{\text {geo }}$ values into seven grades or classes (Table 2). The $I_{\text {geo }}$ factor is not readily comparable to the other indices of metal enrichment due to the nature of the $I_{\text {geo }}$ calculation, which involves a $\log$ function and a background multiplication of 1.5 (Abrahim and Parker, 2008).

\section{Contamination Factor (CF)}

The Contamination Factor (CF) and Contamination Degree (CD) are used to assess the pollution load of the sediments with respect to heavy metals (Manoj et al., 2012). The $\mathrm{CF}$ is the ratio obtained by dividing the concentration of each metal in the sediment by baseline or background value (Varol, 2011). CF for each metal was determined by the following formula (Hakanson, 1980):

$$
C F=\frac{\text { Measured metal concentration }}{\text { Background concentration of the same metal }}
$$

$C D$ for each site was calculated as sum of all contamination factors (Ahdy and Khaled, 2009). Hakanson (1980) has provided four grade ratings of sediments based on CF values (Table 2).

\begin{tabular}{|c|c|c|}
\hline \multicolumn{3}{|l|}{ I-geo values } \\
\hline Müller (1981) & Class & Sediment quality \\
\hline$\leq 0$ & 0 & Unpolluted \\
\hline $0-1$ & 1 & Unpolluted to moderately polluted \\
\hline $1-2$ & 2 & Moderately polluted \\
\hline $2-3$ & 3 & Moderately to strongly polluted \\
\hline $3-4$ & 4 & Strongly polluted \\
\hline $4-5$ & 5 & Strongly to extremely polluted \\
\hline$\geq 6$ & 6 & Extremely polluted \\
\hline \multicolumn{3}{|l|}{ CF values } \\
\hline Hakanson (1980) & Class & Sediment quality \\
\hline $\mathrm{CF}<1$ & 1 & Low $\mathrm{CF}$ \\
\hline $1 \leq \mathrm{CF}<3$ & 2 & Moderate CF \\
\hline $3 \leq \mathrm{CF}<6$ & 3 & Considerable $\mathrm{CF}$ \\
\hline $\mathrm{CF} \geq 6$ & 4 & Very high CF \\
\hline
\end{tabular}

Table 2. Index classification of sediment quality (Müller, 1981) 


\section{Pollution Load Index (PLI)}

Pollution Load Index (PLI) is used to find out the mutual pollution effect at different stations by the different elements in soils and sediments (El-Sammak and Abdul-Kassim, 1999). The PLI gave an assessment of the overall toxicity status of the each sampling site and also it is a result of the contribution of the measured seven metals. PLI for each site was determinedas the nth root of the multiplications of the contents $\left(C F_{\text {metals }}\right)$ by the following equation proposed by Tomlinson et al. (1980):

$$
P L I=\sqrt[n]{(C F 1 \times C F 2 \times C F 3 \times \ldots \times C F n)}
$$

where, $C F$ is the contamination factor and $\mathrm{n}$ is the number of metals. The $P L I$ value of $>1$ is polluted, whereas $<1$ indicates no pollution (Harikumar et al., 2009). This index is quickly understood by unskilled personal in order to compare the pollution status of different places.

\section{Results and Discussion}

\section{Physico-Chemical Characteristics of river Water and Sediment}

The values of physico-chemical parameters measured in the Meghna river water at different sites are given in Table 3. The mean values of temperature, $\mathrm{pH}$, TDS, EC, turbidity, DO, BOD and COD were $25.45^{\circ} \mathrm{C}, 6.85,43.65$ $\mathrm{mg} \mathrm{L}^{-1}, 87.23 \mu \mathrm{S} \mathrm{cm}^{-1}, 14.97 \mathrm{FTU}, 6.97,5.3$ and 57.31 $\mathrm{mg} \mathrm{\textrm {L } ^ { - 1 }}$ on the Right bank, respectively and $25.15^{\circ} \mathrm{C}$, 7.48, $43.68 \mathrm{mg} \mathrm{L}^{-1}, 87.34 \mu \mathrm{S} \mathrm{cm}^{-1}, 11.61 \mathrm{FTU}, 7.64$, 4.34 and $66.68 \mathrm{mg} \mathrm{L}^{-1}$ on the Left bank, respectively. The result showed no significant differences in physicochemical parameters values between both banks. Physico-chemical parameters play an important role into system restoration maintenance and self-regulation of water quality (Bharti and Singh, 2013). The measured $\mathrm{pH}$ values of the Meghna river water were between slightly acidic to moderately alkaline during the study period. The $\mathrm{pH}$ has relationship with the solubility and accumulation of heavy metal in river water as well as sediments according to Singh et al. (2012). Temperature, $\mathrm{pH}, \mathrm{DO}$, TDS and EC of the Meghna river water were within the acceptable limit during the study period but turbidity, BOD and COD values were higher than the acceptable limit of DoE (1997) standard of Bangladesh for drinking water. The physico-chemical parameters values of the present study were compared with other rivers of Bangladesh (Table 4). The measured mean values of $\mathrm{pH}$, DO, TDS, EC and turbidity were lower but BOD and COD were higher than the Ganges and Brahmaputra river recommended by Tareq et al. (2013). According to Rahman and Huda (2012), the mean values of temperature, $\mathrm{pH}$, TDS, EC, turbidity, DO were higher but BOD were lower in the Padma river than the present study. The mean values of temperature, $\mathrm{pH}$, TDS, EC were higher but DO, BOD were lower of the present study than the Buriganga river (Hasan et al., 2009). Islam et al. (2012) investigated that temperature, TDS, EC were higher but $\mathrm{pH}, \mathrm{DO}$ were lower in Dhaleshwari river than present study. Alam et al. (2007) found the mean values of $\mathrm{pH}, \mathrm{DO}, \mathrm{BOD}$ and COD lower in the Surma river than the present study. The mean values of $\mathrm{pH}$, TDS, EC were lower but temperature were higher in the present study than the Shitalakhya, Turag and Bongshi rivers according to Sikder et al. (2013).

The range of $\mathrm{pH}$ and Organic Matter $(\mathrm{OM})$ in the Meghna river sediment were 6.95-7.56 and 0.2121$5.9189 \%$ with mean values of 7.2382 and $1.7216 \%$ respectively (Table 5). The mean values of $\mathrm{pH}$ and $\mathrm{OM}$ were found 7.17 and $2.2631 \%$, respectively on the Right bank sediment and 7.32 and $1.0719 \%$, respectively on the Left bank. The result showed that $\mathrm{pH}$ was nearly same on the both bank but OM was higher on the Right bank sediment. The neutral to slightly alkaline $\mathrm{pH}$, probably related to carbonate nature of the sediment (Barakat et al., 2012) and the presence of organic matter can influence the accumulation of heavy metals in the sediments (Suthar et al., 2009; Mohiuddin et al., 2010; Manoj et al., 2012). pH mean value in the Buriganga river was lower but in the Shitalakhya river was nearly same and organic matter in the both rivers were lower as reported by Islam et al. (2014) than the present study.

\section{Heavy Metals in Water}

The heavy metal concentrations for each sampling site found in water in this study and different standard and guidelines are shown in Table 6. The mean heavy metal concentrations were observed in water in decreasing order of $\mathrm{Fe}>\mathrm{Zn}>\mathrm{Cr}>\mathrm{Mn}>\mathrm{Cd}$ but $\mathrm{Pb}$ and $\mathrm{Ni}$ were found below detection limit. The mean concentrations of $\mathrm{Cd}, \mathrm{Cr}, \mathrm{Fe}, \mathrm{Mn}$ and $\mathrm{Zn}$ were 0.0027 , $0.0202,1.0848,0.0124$ and $0.0357 \mathrm{mg} \mathrm{L}^{-1}$, respectively on the Right bank and 0.0033, 0.0520, 0.9475, 0.0045 and $0.0374 \mathrm{mg} \mathrm{L}^{-1}$, respectively on the Left bank. The result showed that $\mathrm{Fe}$ and $\mathrm{Mn}$ were found higher but $\mathrm{Cd}$, $\mathrm{Cr}$ and $\mathrm{Zn}$ were lower on the Right bank water than the Left bank. The variation of concentration of heavy metal from locations to locations may be correlated with the flow of the rivers and location of industries and their waste disposal system (Alam, 2003). The average concentration of $\mathrm{Cd}, \mathrm{Cr}, \mathrm{Mn}$ and $\mathrm{Zn}$ were found lower but Iron (Fe) was higher in the Meghna river than DoE (1997) standard, WHO (1993) and USEPA (2008) guidelines. The heavy metal concentrations in water of the Meghna river were compared with other rivers of Bangladesh (Table 8). In the Buriganga river, the mean concentrations of $\mathrm{Cd}, \mathrm{Cr}$ and $\mathrm{Zn}$ were investigated higher but $\mathrm{Fe}$ was lower than the present study according to Bhuiyan et al. (2015). The mean concentrations of Cd 
and $\mathrm{Mn}$ were found higher but $\mathrm{Zn}$ was lower as reported by Mokaddes et al. (2013) in the Shitalakhya, Turag and Balu river than the present investigation. According to
Ahmed et al. (2012), the mean concentration of Cd was lower but $\mathrm{Cr}$ was higher in the Dhaleshwari river than present investigation.

Table 3. The values of physico-chemical parameters of the Meghna river water

\begin{tabular}{|c|c|c|c|c|c|c|c|c|}
\hline Sampling sites & $\begin{array}{l}\text { Temperature } \\
\left({ }^{\circ} \mathrm{C}\right)\end{array}$ & $\mathrm{pH}$ & $\begin{array}{l}\text { TDS } \\
(\mathrm{mg} / \mathrm{l})\end{array}$ & $\begin{array}{l}\mathrm{EC} \\
(\mu \mathrm{S} / \mathrm{cm})\end{array}$ & $\begin{array}{l}\text { Turbidity } \\
\text { (FTU) }\end{array}$ & $\begin{array}{l}\mathrm{DO} \\
(\mathrm{mg} / \mathrm{l})\end{array}$ & $\begin{array}{l}\text { BOD } \\
(\mathrm{mg} / \mathrm{l})\end{array}$ & $\begin{array}{l}\text { COD } \\
(\mathrm{mg} / \mathrm{l})\end{array}$ \\
\hline $\mathrm{R}-1$ & 25.100 & 7.030 & 30.700 & 61.300 & 11.720 & 7.230 & 6.100 & 62.520 \\
\hline $\mathrm{R}-2$ & 27.300 & 6.070 & 91.100 & 182.200 & 25.100 & 4.660 & 10.100 & 93.780 \\
\hline $\mathrm{R}-3$ & 25.400 & 7.030 & 36.000 & 71.900 & 18.980 & 7.030 & 4.900 & 52.100 \\
\hline R-4 & 25.100 & 6.900 & 34.300 & 68.600 & 13.750 & 7.100 & 7.100 & 72.940 \\
\hline $\mathrm{R}-5$ & 25.000 & 6.980 & 35.800 & 71.500 & 9.960 & 8.350 & 1.200 & 20.840 \\
\hline $\mathrm{R}-6$ & 24.800 & 7.100 & 34.000 & 67.900 & 10.310 & 7.500 & 2.400 & 41.680 \\
\hline L-1 & 25.000 & 7.280 & 34.400 & 68.800 & 9.600 & 8.130 & 1.800 & 62.520 \\
\hline L-2 & 25.000 & 7.920 & 34.100 & 68.200 & 10.640 & 7.630 & 3.400 & 72.940 \\
\hline L-3 & 25.800 & 8.010 & 80.600 & 161.200 & 11.180 & 7.180 & 9.700 & 114.620 \\
\hline L-4 & 25.100 & 7.350 & 35.300 & 70.500 & 9.990 & 8.200 & 2.300 & 31.260 \\
\hline L-5 & 24.900 & 6.850 & 34.000 & 68.000 & 16.610 & 7.050 & 4.500 & 52.100 \\
\hline Maximum & 27.300 & 8.010 & 91.100 & 182.200 & 25.100 & 8.350 & 10.100 & 114.620 \\
\hline Minimum & 24.800 & 6.070 & 30.700 & 61.300 & 9.600 & 4.660 & 1.200 & 20.840 \\
\hline Mean & 25.300 & 7.230 & 43.660 & 87.280 & 13.440 & 7.280 & 4.860 & 61.570 \\
\hline SD. & 0.711 & 0.392 & 21.035 & 42.092 & 4.912 & 0.995 & 3.083 & 26.953 \\
\hline DoE (1997) standard & $20-30$ & $6.5-8.5$ & 1000.000 & 350.000 & 10.000 & 6.000 & 0.200 & 4.000 \\
\hline
\end{tabular}

SD- Standard Deviation

Table 4. Comparison of physico-chemical parameters of the Meghnariver with other rivers of Bangladesh

\begin{tabular}{|c|c|c|c|c|c|c|c|c|c|}
\hline \multirow[b]{2}{*}{ river } & \multicolumn{8}{|c|}{ Mean Values of Physico-chemical Parameters } & \multirow[b]{2}{*}{ References } \\
\hline & $\begin{array}{l}\text { Temperature } \\
\left({ }^{\circ} \mathrm{C}\right)\end{array}$ & $\mathrm{pH}$ & $\begin{array}{l}\text { TDS } \\
(\mathrm{mg} / \mathrm{l})\end{array}$ & $\begin{array}{l}\mathrm{EC} \\
(\mu \mathrm{S} / \mathrm{cm})\end{array}$ & $\begin{array}{l}\text { Turbidity } \\
\text { (FTU) }\end{array}$ & $\begin{array}{l}\mathrm{DO} \\
(\mathrm{mg} / \mathrm{l})\end{array}$ & $\begin{array}{l}\text { BOD } \\
(\mathrm{mg} / \mathrm{l})\end{array}$ & $\begin{array}{l}\text { COD } \\
(\mathrm{mg} / \mathrm{l})\end{array}$ & \\
\hline Meghna river & 25.3 & 7.23 & 43.66 & 87.28 & 13.44 & 7.28 & 4.86 & 61.57 & Present study \\
\hline Ganges river & - & 7.87 & 260 & 286 & 82.78 & 7.65 & 2.6 & 51 & Tareq et al. (2013) \\
\hline Brahmaputra river & - & 7.66 & 155 & 168 & 64.4 & 7.52 & 2.63 & 41 & Tareq et al. (2013) \\
\hline Padma river & 27.5 & 7.67 & 84.08 & 162.17 & 53.37 & 7.79 & 4.25 & - & Rahman and Huda (2012) \\
\hline Buriganga river & 25.86 & 7.31 & 629.33 & 800.49 & - & 4.57 & 3.65 & - & Hasan et al. (2009) \\
\hline Dhaleshwari river & 29.03 & 6.15 & 173.10 & 319.43 & - & 6.46 & - & - & Islam et al. (2012) \\
\hline Surma river & - & 6.11 & - & - & - & 5.62 & 0.94 & 1.43 & Alam et al. (2007) \\
\hline Shitalakhya river & 25.15 & 8.1 & 737 & 1087.5 & - & - & - & 120 & Sikder et al. (2013) \\
\hline Turag river & 21.55 & 7.45 & 410.5 & 579.5 & - & - & - & 35 & Sikder et al. (2013) \\
\hline Bongshi river & 20.86 & 7.43 & 420.33 & 594 & - & - & - & 35 & Sikder et al. (2013) \\
\hline
\end{tabular}

Table 5. Values of $\mathrm{pH}$ and $\mathrm{OM}$ in the Meghna river sediment

\begin{tabular}{lll}
\hline Sampling sites & $\mathrm{pH}$ & OM (\%) \\
\hline R-1 & 7.2500 & 1.4850 \\
R-2 & 6.9500 & 5.9189 \\
R-3 & 7.1600 & 4.0308 \\
R-4 & 7.1900 & 1.3153 \\
R-5 & 7.2500 & 0.2121 \\
R-6 & 7.2200 & 0.6164 \\
L-1 & 7.4100 & 2.1921 \\
L-2 & 7.4500 & 0.6577 \\
L-3 & 7.5600 & 0.7972 \\
L-4 & 7.1400 & 0.6164 \\
L-5 & 7.0400 & 1.0962 \\
Maximum & 7.5600 & 5.9189 \\
Minimum & 6.9500 & 0.2121 \\
Mean & 7.2382 & 1.7216 \\
SD. & 0.1785 & 1.7462 \\
\hline
\end{tabular}

SD- Standard Deviation 
Table 6. Concentration (mg/l) of heavy metals in the Meghna river water

\begin{tabular}{|c|c|c|c|c|c|c|c|}
\hline Sampling sites & $\mathrm{Cd}$ & $\mathrm{Cr}$ & $\mathrm{Fe}$ & $\mathrm{Mn}$ & $\mathrm{Pb}$ & $\mathrm{Ni}$ & $\mathrm{Zn}$ \\
\hline $\mathrm{R}-1$ & 0.0029 & 0.02320 & 1.4640 & 0.01740 & BDL & $\mathrm{BDL}$ & 0.0283 \\
\hline $\mathrm{R}-2$ & 0.0032 & 0.01930 & 0.4676 & 0.01530 & BDL & BDL & 0.0267 \\
\hline $\mathrm{R}-3$ & 0.0012 & 0.00920 & 1.4347 & 0.01590 & $\mathrm{BDL}$ & BDL & 0.0226 \\
\hline $\mathrm{R}-4$ & 0.0047 & 0.00630 & 1.4064 & 0.02500 & $\mathrm{BDL}$ & BDL & 0.0781 \\
\hline $\mathrm{R}-5$ & 0.0032 & 0.01470 & 0.9257 & 0.00050 & $\mathrm{BDL}$ & $\mathrm{BDL}$ & 0.0242 \\
\hline R-6 & 0.0014 & 0.04840 & 0.8107 & 0.00030 & BDL & BDL & 0.0343 \\
\hline L-1 & 0.0017 & 0.04420 & 0.6014 & 0.00920 & $\mathrm{BDL}$ & $\mathrm{BDL}$ & 0.0109 \\
\hline $\mathrm{L}-2$ & 0.0026 & 0.02520 & 0.5015 & 0.00860 & $\mathrm{BDL}$ & $\mathrm{BDL}$ & 0.0175 \\
\hline L-3 & 0.0023 & 0.06950 & 0.9012 & 0.00080 & BDL & BDL & 0.0365 \\
\hline L-4 & 0.0071 & 0.07370 & 1.5987 & 0.00150 & BDL & BDL & 0.1122 \\
\hline L-5 & 0.0029 & 0.04740 & 1.1350 & 0.00230 & $\mathrm{BDL}$ & BDL & 0.0100 \\
\hline Maximum & 0.0071 & 0.07370 & 1.5987 & 0.02500 & & & 0.1122 \\
\hline Minimum & 0.0012 & 0.00630 & 0.4676 & 0.00030 & & & 0.0100 \\
\hline Mean & 0.0030 & 0.03460 & 1.0224 & 0.00880 & & & 0.0364 \\
\hline SD. & 0.0016 & 0.02343 & 0.4102 & 0.00854 & & & 0.0311 \\
\hline DoE (1997) standard & 0.0050 & 0.05000 & $0.3-1.0$ & 0.10000 & 0.05 & 0.10 & 5.0000 \\
\hline WHO (1993) guideline & 0.0030 & 0.05000 & NA & 0.50000 & 0.01 & 0.02 & 3.0000 \\
\hline USEPA (2008) guideline & 0.0050 & 0.10000 & 0.3000 & 0.05000 & NA & NA & 5.0000 \\
\hline
\end{tabular}

SD- Standard Deviation, BDL- Below Detection Limit, NA- Not Available

Table 7. Correlation coefficients (r) among heavy metal in water sample

\begin{tabular}{llllll}
\hline Water/Water & $\mathrm{Cd}$ & $\mathrm{Cr}$ & $\mathrm{Fe}$ & $\mathrm{Mn}$ & \\
\hline $\mathrm{Cd}$ & 1.00 & & & & \\
$\mathrm{Cr}$ & 0.244 & 1.00 & & \\
$\mathrm{Fe}$ & 0.477 & 0.018 & 1.00 & 1.00 \\
$\mathrm{Mn}$ & 0.021 & $-0.715^{*}$ & 0.226 & 0.066 \\
$\mathrm{Zn}$ & $0.864^{* *}$ & 0.300 & 0.588 & 1.00 \\
\hline
\end{tabular}

**. Correlation is significant at the 0.01 level (2-tailed); *. Correlation is significant at the 0.05 level (2-tailed)

Table 8. Comparison of heavy metal concentrations of the Meghna river water and sediment with other rivers of Bangladesh

\begin{tabular}{|c|c|c|c|c|c|c|c|c|}
\hline \multirow[b]{2}{*}{ river } & \multicolumn{7}{|c|}{ Mean Concentrations of Heavy Metal } & \multirow[b]{2}{*}{ References } \\
\hline & $\mathrm{Cd}$ & $\mathrm{Cr}$ & $\mathrm{Fe}$ & $\mathrm{Mn}$ & $\mathrm{Pb}$ & $\mathrm{Ni}$ & $\mathrm{Zn}$ & \\
\hline \multicolumn{9}{|l|}{ Water } \\
\hline Meghna river & 0.0030 & 0.0346 & 1.0224 & 0.0088 & - & - & 0.0364 & Present study \\
\hline Buriganga river & 0.0590 & 0.114 & 0.612 & 0.157 & 0.1119 & 0.150 & 0.3320 & Bhuiyan et al. (2015) \\
\hline Shitalakhya river & 0.0110 & - & - & 0.0514 & 0.0011 & - & 0.0051 & Mokaddes et al. (2013) \\
\hline Turag river & 0.0136 & - & - & 0.0555 & 0.0021 & - & 0.0191 & Mokaddes et al. (2013) \\
\hline Balu river & 0.0137 & - & - & 0.0470 & 0.0010 & - & 0.0101 & Mokaddes et al. (2013) \\
\hline Dhaleshwari river & 0.0010 & 0.130 & - & - & 0.201 & - & - & Ahmed et al. (2012) \\
\hline Khiru river & 0.1275 & - & - & 0.1672 & 0.0221 & - & 0.0065 & Rashid et al. (2012) \\
\hline \multicolumn{9}{|l|}{ Sediment } \\
\hline Meghna river & 0.2300 & 31.739 & 1281.42 & 442.596 & 9.4702 & 76.116 & 79.021 & Present study \\
\hline Buriganga river & 0.8200 & 101.2 & - & - & 79.4 & - & 502.26 & Saha and Hossain (2011) \\
\hline Shitalakhya river & 5.0100 & 63.22 & - & - & 28.36 & 39.22 & 75 & Islam et al. (2014) \\
\hline Turag river & 0.2800 & 43.02 & - & - & 32.78 & - & 139.48 & Banu et al. (2013) \\
\hline Daleshwari river & 2.0830 & 27.393 & - & - & 15.797 & - & - & Ahmed et al. (2012) \\
\hline Bangshi river & 0.6100 & 98.10 & - & 483.44 & 59.99 & 25.67 & 117.15 & Rahman et al. (2014) \\
\hline Korotoa river & 1.2000 & 109 & - & - & 58 & 95 & - & Islam et al. (2015) \\
\hline
\end{tabular}

Pearson's correlation coefficients of heavy metals studied using statistical software SPSS (version 22.0) in the Meghna river water have been summarized in the Table 7. The relationship between the heavy metals may offer remarkable information on the sources and pathway of heavy metals. Correlation analysis shows significant positive correlation between $\mathrm{Zn}-\mathrm{Cd}(\mathrm{r}=0.864)$ at $\mathrm{p}<0.01$ level where as $\mathrm{Mn}$ is significantly but inversely correlated with $\mathrm{Cr}(\mathrm{r}=-0.715)$ at $\mathrm{p}<0.05$ level. The high significant correlations between heavy metals may reflect the fact that these heavy metals had similar pollution levels and similar pollution sources (Armah et al., 2010). On the other hand the rest of elemental pairs show no significant correlation with each other, suggesting that these metals are not associated with each other and lack of their identical behavior transport in aquatic environment. 


\section{Heavy Metals in Sediments}

The heavy metal concentrations in the river sediments at all sampling sites and comparison with different Sediment Quality Guidelines (SQG) are given in Table 9. The mean concentrations of analyzed heavy metal were observed in sediment in decreasing order of $\mathrm{Fe}>\mathrm{Mn}>\mathrm{Zn}>\mathrm{Ni}>\mathrm{Cr}>\mathrm{Pb}>\mathrm{Cd}$. Ni was found in all sediment samples but was not found in water samples because $\mathrm{Ni}$ is mainly transported in the form of a precipitated coating on particles and in association with organic matter. Ni may also be absorbed on to clayparticles and via uptake by biota. Absorption process may be reversed leading to release of $\mathrm{Ni}$ from the sediment (Ahmad et al., 2010). The mean concentrations of $\mathrm{Cd}, \mathrm{Cr}, \mathrm{Fe}, \mathrm{Mn}, \mathrm{Pb}, \mathrm{Ni}$ and $\mathrm{Zn}$ in sediments were $0.2808,35.7464,1293.85,411.7323,12.6384,74.4498$ and $96.6593 \mathrm{mg} \mathrm{kg}^{-1}$, respectively on the Right bank and $0.1698,26.9322,1266.496,479.6334,5.6684,78.1162$ and $57.8557 \mathrm{mg} \mathrm{kg}^{-1}$, respectively on the Left bank. The result showed that $\mathrm{Cd}, \mathrm{Cr}, \mathrm{Fe}, \mathrm{Pb}$ and $\mathrm{Zn}$ concentrations were higher but $\mathrm{Mn}$ and $\mathrm{Ni}$ were lower on the Right bank than the Left bank. Among all sampling sites most all measured heavy metal concentrations were found higher which is situated near a shipyard. High concentration of heavy metals release from base material (e.g., steel, stainless steel, galvanized steel, aluminum, copper-nickel and other copper alloys), abrasive blasting materials (e.g., coal slag, copper slag, nickel slag, glass, steel grit, garnet, silica sand), surface coatings (e.g., preconstruction primers, anticorrosive and antifouling paints) and welding materials in shipyard (Kura et al., 2006; OSHA, 2006) and deposited in river sediment. The mean concentrations of $\mathrm{Cd}, \mathrm{Pb}$ and $\mathrm{Zn}$ in the Meghna river sediments were found lower but $\mathrm{Ni}$ was found higher than WHO (2004), USEPA (1999) and CCME
(1999) Sediment Quality Guidelines (SQG). Fe and Mn mean concentrations were higher than USEPA (1999) sediment quality guideline and $\mathrm{Cr}$ mean concentration was higher than WHO (2004) but lower than CCME (1999) sediment quality guidelines. The heavy metal concentrations in sediment of the Meghna river were compared with other rivers of Bangladesh (Table 8). The mean concentrations of $\mathrm{Cd}, \mathrm{Cr}, \mathrm{Pb}$ and $\mathrm{Zn}$ were higher as reported by Saha and Hossain (2011) in the Buriganga river than the present investigation. $\mathrm{Cd}, \mathrm{Cr}, \mathrm{Pb}$ mean concentrations were found higher in Shitalakhya (Islam et al., 2014) and Turag (Banu et al., 2013) rivers than present study but $\mathrm{Ni}$ and $\mathrm{Zn}$ were found lower in Shitalakhya river. In the Dhaleshwari river, the mean concentrations of $\mathrm{Cd}$ and $\mathrm{Pb}$ were found higher but $\mathrm{Cr}$ was lower as recommended by Ahmed et al. (2012) than present measured concentrations. The mean concentrations of $\mathrm{Cd}, \mathrm{Cr}, \mathrm{Mn}, \mathrm{Pb}$ and $\mathrm{Zn}$ were investigated higher but $\mathrm{Ni}$ was lower in the Bangshi river reported by Rahman et al. (2014) than this study. According to Islam et al. (2015), the mean concentrations of $\mathrm{Cd}, \mathrm{Cr}, \mathrm{Pb}$ and $\mathrm{Ni}$ were measured in the Korotoa river than the present study.

Pearson's correlation analysis shows significant correlation between $\mathrm{Zn}-\mathrm{Cd}(\mathrm{r}=0.894), \mathrm{Zn}-\mathrm{Fe}(\mathrm{r}=0.736)$, $\mathrm{Ni}-\mathrm{Pb}(\mathrm{r}=0.930), \mathrm{Pb}-\mathrm{Cd}(\mathrm{r}=0.977)$ and Fe-Cr $(\mathrm{r}=0.736)$ at $\mathrm{p}<0.01$ level whereas significant correlation between $\mathrm{Zn}-\mathrm{Ni}(\mathrm{r}=0.674)$ and $\mathrm{Ni}-\mathrm{Cd}(\mathrm{r}=0.679)$ at $\mathrm{p}<0.05$ level (Table 10). These highly significant positive correlations between heavy metals suggest the possibility of common sources of origins which may be anthropogenic (Armah et al., 2010). On the other hand the rest of elemental pairs show no significant correlation with each other in sediments that could be indication of separate source input or sources of pollution.

Table 9. Concentration $(\mathrm{mg} / \mathrm{kg})$ of heavy metals in the Meghna river sediments

\begin{tabular}{lllllrrr} 
Sampling sites & $\mathrm{Cd}$ & $\mathrm{Cr}$ & $\mathrm{Fe}$ & $\mathrm{Mn}$ & $\mathrm{Pb}$ & $\mathrm{Ni}$ & $\mathrm{Zn}$ \\
\hline R-1 & 0.2019 & 48.1779 & 1273.560 & 472.019 & 7.7426 & 63.5384 & 86.9903 \\
$\mathrm{R}-2$ & 0.3300 & 56.9500 & 1324.510 & 396.600 & 14.8750 & 36.4850 & 121.7500 \\
R-3 & 0.2100 & 42.0000 & 1311.970 & 616.300 & 7.1150 & 57.1650 & 81.3750 \\
R-4 & 0.6900 & 31.0550 & 1321.490 & 381.050 & 44.8550 & 218.8500 & 204.7600 \\
R-5 & 0.1633 & 23.4505 & 1270.790 & 352.525 & 0.4059 & 42.4158 & 49.9158 \\
R-6 & 0.0900 & 12.8450 & 1260.780 & 251.900 & 0.8372 & 28.2450 & 35.1650 \\
L-1 & 0.1666 & 38.4898 & 1316.170 & 502.778 & 8.2525 & 185.1620 & 80.8838 \\
L-2 & 0.1470 & 42.1078 & 1294.830 & 789.510 & 5.9363 & 55.2451 & 73.5245 \\
L-3 & 0.2079 & 16.4703 & 1207.230 & 230.297 & 3.3745 & 47.5643 & 32.7524 \\
L-4 & 0.1969 & 12.6565 & 1231.620 & 168.737 & 6.6139 & 66.2020 & 29.4141 \\
L-5 & 0.1310 & 24.9368 & 1282.630 & 706.845 & 4.1650 & 36.4078 & 72.7038 \\
Maximum & 0.6900 & 56.9500 & 1324.510 & 789.510 & 44.8550 & 218.8500 & 204.7600 \\
Minimum & 0.0900 & 12.6560 & 1207.230 & 168.737 & 0.4059 & 28.2450 & 29.4140 \\
Mean & 0.2300 & 31.7390 & 1281.420 & 442.596 & 9.4702 & 76.1160 & 79.0210 \\
SD & 0.1640 & 14.9460 & 37.905 & 198.818 & 12.3850 & 63.8010 & 50.1510 \\
WHO (2004) SQG & 6.0000 & 25.0000 & NA & NA & NA & 20.0000 & 123.0000 \\
USEPA (1999) SQG & 0.6000 & 25.0000 & 30.000 & 30.000 & 40.0000 & 16.0000 & 110.0000 \\
CCME (1999) SQG & 0.6000 & 37.3000 & NA & NA & 35.0000 & NA & 123.0000 \\
\hline SD- Standar Deve
\end{tabular}

SD- Standard Deviation, SQG-Sediment Quality Guideline, NA-Not Available 


\section{Assessment of Sediment Heavy Metals Contamination}

The heavy metal contaminations in the sediments were evaluated by comparison with the sediment quality guideline proposed by USEPA (1989) (Table 11). The mean concentrations of the present study showed that Meghna river sediments were unpolluted for $\mathrm{Cd}, \mathrm{Pb}$ and $\mathrm{Zn}$; moderately polluted for $\mathrm{Cr}$ and $\mathrm{Mn}$ and heavily polluted for $\mathrm{Ni}$.

According to the Müller (1969) formula, the calculated results of $I_{\text {geo }}$ values of the sediments are given in Table 12. According to Müller (1981) scale (Table 2), a qualitative scale of pollution intensity (Farkas et al., 2007), $\mathrm{I}_{\text {geo }}$ values indicated that Meghna river sediments are unpolluted $\left(\mathrm{I}_{\text {geo }}<0\right)$ for all sampling sites for all metals except R-4 sampling site for $\mathrm{Cd}, \mathrm{Pb}, \mathrm{Ni}, \mathrm{Zn}$ and $\mathrm{L}-1$ site for Ni. Sediments in $\mathrm{R}-4$ site for $\mathrm{Cd}, \mathrm{Pb}, \mathrm{Zn}$ and $\mathrm{L}-1$ for $\mathrm{Ni}$ are unpolluted to moderately polluted $\left(0<\mathrm{I}_{\text {geo }}>1\right)$ but for $\mathrm{Ni}$ in $\mathrm{R}-4$ site is moderately polluted $\left(1<\mathrm{I}_{\text {geo }}>2\right)$.

Considering calculated Contamination Factor (CF) and degree of contamination (CD) (Table 13), maximum contamination factor was found in R-4 sampling site where the degree of contamination is 10.736 . $\mathrm{CF}>3$ (indicating considerable contamination) was found in R-4 sampling site for $\mathrm{Ni}$ and $\mathrm{CF}>1$ (indicating moderate contamination) found in R-2 sampling sites for Cd and in R-4 sampling site for $\mathrm{Cd}, \mathrm{Pb}$ and $\mathrm{Zn}$. Other all the sampling sites have Contamination Factor $(\mathrm{CF})>1$ (indicating low contamination) for all tested heavy metals. The mean values of the CF were found $\mathrm{Cd}$ : 0.767 (low contamination); $\mathrm{Cr}$ : 0.352 (low contamination); Fe: 0.026 (low contamination); Mn: 0.52 (low contamination); $\mathrm{Pb}$ : 0.473 (low contamination); Ni: 1.119 (moderate contamination) and $\mathrm{Zn:} 0.831$ (low contamination). On the basis of the mean values of $\mathrm{CF}$, sediments are enriched for metals in the following order: $\mathrm{Ni}>\mathrm{Zn}>\mathrm{Cd}>\mathrm{Mn}>\mathrm{Pb}>\mathrm{Cr}>\mathrm{Fe}$.

Table 10. Correlation coefficients (r) among heavy metal in sediment sample

\begin{tabular}{llllllll}
\hline Sediment/Sediment & $\mathrm{Cd}$ & $\mathrm{Cr}$ & $\mathrm{Fe}$ & $\mathrm{Mn}$ & $\mathrm{Pb}$ & $\mathrm{Ni}$ & $\mathrm{Zn}$ \\
\hline $\mathrm{Cd}$ & 1.00 & & & & & & \\
$\mathrm{Cr}$ & 0.208 & 1.00 & & & & \\
$\mathrm{Fe}$ & 0.415 & $0.736^{* *}$ & 1.00 & & & \\
$\mathrm{Mn}$ & -0.152 & 0.544 & 0.557 & 1.00 & & \\
$\mathrm{~Pb}$ & $0.977^{* *}$ & 0.236 & 0.504 & -0.043 & 1.00 & $0.756^{* *}$ & 1.00 \\
$\mathrm{Ni}$ & $0.679^{* *}$ & 0.115 & 0.453 & -0.007 & $0.930^{* *}$ & $0.674^{*}$ & 1.00 \\
$\mathrm{Zn}$ & $0.894^{* *}$ & 0.516 & $0.736^{* *}$ & 0.219 &
\end{tabular}

**. Correlation is significant at the 0.01 level (2-tailed); *. Correlation is significant at the 0.05 level (2-tailed)

Table 11. Assessment of sediments Heavy Metals Contamination ( $\mathrm{mg} / \mathrm{kg}$ ) According to USEPA (1989) guideline

\begin{tabular}{llllr}
\hline Heavy metals & Not polluted & Moderately polluted & Heavily polluted & Present study \\
\hline $\mathrm{Cd}$ & $\mathrm{ND}$ & $\mathrm{ND}$ & $>6$ & 0.2300 \\
$\mathrm{Cr}$ & $<25$ & $25-75$ & $>75$ & 31.7390 \\
$\mathrm{Fe}$ & $\mathrm{ND}$ & $\mathrm{ND}$ & $\mathrm{ND}$ & 1281.4160 \\
$\mathrm{Mn}$ & $<300$ & $300-500$ & $>500$ & 442.5960 \\
$\mathrm{~Pb}$ & $<40$ & $40-60$ & $>60$ & 9.4702 \\
$\mathrm{Ni}$ & $<20$ & $20-50$ & $>50$ & 76.1160 \\
$\mathrm{Zn}$ & $<90$ & $90-200$ & $>200$ & 79.0210 \\
\hline
\end{tabular}

ND-Not Detectable

Table 12. Geo-accumulation Index $\left(\mathrm{I}_{\text {geo }}\right)$ values of heavy metals of the Meghna river sediments

\begin{tabular}{|c|c|c|c|c|c|c|c|}
\hline \multirow[b]{2}{*}{ Sampling sites } & \multicolumn{7}{|c|}{ Geo-accumulation Index $\left(\mathrm{I}_{\mathrm{geo}}\right)$} \\
\hline & $\mathrm{Cd}$ & $\mathrm{Cr}$ & $\mathrm{Fe}$ & $\mathrm{Mn}$ & $\mathrm{Pb}$ & $\mathrm{Ni}$ & $\mathrm{Zn}$ \\
\hline $\mathrm{R}-1$ & -1.156 & -1.486 & -5.7960 & -1.433 & -1.954 & -0.683 & -0.712 \\
\hline $\mathrm{R}-2$ & -0.447 & -1.245 & -5.7400 & -1.684 & -1.012 & -1.483 & -0.227 \\
\hline $\mathrm{R}-3$ & -1.099 & -1.840 & -5.7540 & -1.048 & -2.076 & -0.835 & -0.808 \\
\hline $\mathrm{R}-4$ & 0.617 & -2.120 & -5.7430 & -1.742 & 0.580 & 1.101 & 0.522 \\
\hline R-5 & -1.462 & -2.525 & -5.7990 & -1.854 & -6.207 & -1.266 & -1.513 \\
\hline $\mathrm{R}-6$ & -2.322 & -3.394 & -5.8110 & -2.339 & -5.163 & -1.852 & -2.018 \\
\hline L-1 & -1.433 & -1.810 & -5.7490 & -1.342 & -1.862 & 0.860 & -0.817 \\
\hline $\mathrm{L}-2$ & -1.614 & -1.680 & -5.7720 & -0.691 & -2.337 & -0.884 & -0.954 \\
\hline L-3 & -1.114 & -3.035 & -5.8740 & -2.468 & -3.152 & -1.101 & -2.121 \\
\hline L-4 & -1.192 & -3.415 & -5.8451 & -2.917 & -2.181 & -0.624 & -2.276 \\
\hline L-5 & -1.780 & -2.436 & -5.7860 & -0.851 & -2.848 & -1.486 & -0.971 \\
\hline
\end{tabular}


Table 13. Contamination Factor (CF), Contamination Degree (CD) and Pollution Load Index (PLI) values

\begin{tabular}{|c|c|c|c|c|c|c|c|c|c|}
\hline \multirow{2}{*}{$\begin{array}{l}\text { Sampling } \\
\text { sites }\end{array}$} & \multicolumn{7}{|c|}{ Contamination Factor (CF) } & \multirow{2}{*}{$\begin{array}{l}\text { Degree of } \\
\text { Contamination } \\
\text { (CD) }\end{array}$} & \multirow{2}{*}{$\begin{array}{l}\text { Pollution } \\
\text { Load Index } \\
\text { (PLI) }\end{array}$} \\
\hline & $\mathrm{Cd}$ & $\mathrm{Cr}$ & $\mathrm{Fe}$ & $\mathrm{Mn}$ & $\mathrm{Pb}$ & $\mathrm{Ni}$ & $\mathrm{Zn}$ & & \\
\hline $\mathrm{R}-1$ & 0.673 & 0.535 & 0.026 & 0.555 & 0.387 & 0.934 & 0.915 & 4.025 & 0.403 \\
\hline $\mathrm{R}-2$ & 1.100 & 0.632 & 0.028 & 0.466 & 0.744 & 0.536 & 1.281 & 4.787 & 0.464 \\
\hline $\mathrm{R}-3$ & 0.700 & 0.466 & 0.027 & 0.725 & 0.356 & 0.841 & 0.856 & 3.971 & 0.401 \\
\hline $\mathrm{R}-4$ & 2.300 & 0.345 & 0.028 & 0.448 & 2.242 & 3.218 & 2.155 & 10.736 & 0.765 \\
\hline $\mathrm{R}-5$ & 0.544 & 0.260 & 0.026 & 0.414 & 0.020 & 0.623 & 0.525 & 2.412 & 0.194 \\
\hline $\mathrm{R}-6$ & 0.300 & 0.142 & 0.026 & 0.296 & 0.041 & 0.415 & 0.370 & 1.590 & 0.154 \\
\hline L-1 & 0.555 & 0.427 & 0.027 & 0.591 & 0.412 & 2.723 & 0.851 & 5.586 & 0.449 \\
\hline L-2 & 0.490 & 0.467 & 0.027 & 0.928 & 0.296 & 0.812 & 0.773 & 3.793 & 0.377 \\
\hline L-3 & 0.693 & 0.183 & 0.025 & 0.271 & 0.168 & 0.699 & 0.344 & 2.383 & 0.230 \\
\hline L-4 & 0.656 & 0.141 & 0.026 & 0.198 & 0.330 & 0.973 & 0.309 & 2.633 & 0.241 \\
\hline L-5 & 0.436 & 0.277 & 0.027 & 0.831 & 0.208 & 0.535 & 0.765 & 3.079 & 0.302 \\
\hline Mean & 0.767 & 0.352 & 0.026 & 0.520 & 0.473 & 1.119 & 0.831 & 4.090 & \\
\hline
\end{tabular}

The PLI represents the number of times by which the metal content in the sediment exceeds the background concentration and gives a summative indication of the overall level of heavy metal toxicity in a particular sample (Barakat et al., 2012). According to the Tomlinson et al. (1980) formula, the calculated PLI values of all sampling sites are shown in Table 13. The PLI ranged from 0.154 to 0.765 . The highest PLI value was observed in R-4 sampling site near a shipyard. The present study showed that the PLI values of all sampling sites were lower than 1 that indicating no pollution. The PLI can provide some understanding to the public of the area about the quality of a component of their environment and indicates the trend over time and area (Mohiuddin et al., 2010).

\section{Conclusion}

This research reveals that the measured concentrations of $\mathrm{Cd}, \mathrm{Cr}, \mathrm{Mn}$ and $\mathrm{Zn}$ in the Meghna river water are lower but $\mathrm{Fe}$ is higher than standard guidelines. $\mathrm{Pb}$ and $\mathrm{Ni}$ are found below detection limit in all sampling sites. According to USEPA (1989) sediment quality guideline, sediment are heavily polluted for Ni. According to geo-accumulation index $\left(\mathrm{I}_{\mathrm{geo}}\right)$, all the sampling sites are unpolluted for all studied heavy metals except R-4 sampling site for $\mathrm{Cd}$, $\mathrm{Pb}, \mathrm{Ni}, \mathrm{Zn}$ and $\mathrm{L}-1$ site for Ni. Pollution Load Index (PLI) values showed that all the sampling sites are unpolluted. According to mean Contamination Factor (CF), all the sampling sites are low polluted for all studied heavy metals except $\mathrm{Ni}$ which is moderately polluted. These results clearly indicate the quality of the Meghna river water and sediments to be unpolluted to low polluted. Continuous monitoring and assessment will keep checking the pollution status of the river water and sediment.

\section{Acknowledgment}

The authors deeply thankful to the Biological Research Division, Bangladesh Council of Scientific and Industrial Research (BCSIR), Dhaka-1205, Bangladesh for providing all necessary research facilities.

\section{Author's Contributions}

Mahmud Hassan: Contributed in sampling, laboratory analysis and writing of the manuscript.

Mirza A.T.M. Tanvir Rahman: Contributed in Research designing, organizing and writing of the manuscript.

Badhan Saha: Contributed in sampling preparation and other laboratory analysis.

Abdul Kadir Ibne Kamal: Contributed in research designing.

\section{Ethics}

This article is original and contains unpublished material. The authors have no conflicts of interest in the development and publication of current research.

\section{References}

Abdullah, E.J., 2013. Quality assessment for Shatt AlArab river using heavy metal pollution index and metal index. J. Environ. Earth Sci., 3: 114-120.

Abrahim, G.M.S. and R.J. Parker, 2008. Assessment of heavy metal enrichment factors and the degree of contamination in marine sediments from Tamaki Estuary, Auckland, New Zealand. Environ. Monit. Assess., 136: 227-238.

DOI: $10.1007 / \mathrm{s} 10661-007-9678-2$

Ahdy, H.H.H. and A. Khaled, 2009. Heavy metals contamination in sediments of the western part of Egyptian Mediterranean Sea. Aust. J. Basic Applied Sci., 3: 3330-3336. 
Ahmad, M.K., S. Islam, M.S. Rahman, M.R. Haque and M.M. Islam, 2010. Heavy metals in water, sediment and some fishes of Buriganga river, Bangladesh. Int. J. Environ. Res., 4: 321-332.

Ahmed, A.T.A., S. Mandal, D.A. Chowdhury, A.R.M. Tareq and M.M. Rahman, 2012. Bioaccumulation of some heavy metals in Ayre fish, sediment and water of Dhaleshwari river in dry season. Bangladesh J. Zool., 40: 147-153. DOI: 10.3329/bjz.v40i1.12904

Alam, J.B., A. Hossain, S.K. Khan, B.K. Banik and M.R. Islam et al., 2007. Deterioration of water quality of Surma river. Environ. Monit. Assess., 134: 233-42. DOI: $10.1007 / \mathrm{s} 10661-007-9612-7$

Alam, K., 2003. Cleanup of the Buriganga river: Integrating the environment into decision making. $\mathrm{PhD}$ Dissertation, Murdoch University.

APHA, 1998. Standard methods for the examination of water and wastewater. American Public Health Association, Washington DC, USA

Armah, F.A., S. Obiri, D.O. Yawson, E.E. Onumah and G.T. Yengoh et al., 2010. Anthropogenic sources and environmentally relevant concentrations of heavy metals in surface water of a mining district in Ghana: A multivariate statistical approach. J. Environ. Sci. Health A., 45: 1804-1813. DOI: $10.1080 / 10934529.2010 .513296$

Arnason, J.G. and B. Fletcher, 2003. A 40+ year record of $\mathrm{Cd}, \mathrm{Hg}, \mathrm{Pb}$ and $\mathrm{U}$ deposition in sediments of patroon reservoir, Albany County, NY, USA. Environ. Pollut., 123: 383-391.

DOI: $10.1016 / \mathrm{S} 0269-7491(03) 00015-0$

Banu, Z., M.S.A. Chowdhury, M.D. Hossain and K. Nakagami, 2013. Contamination and ecological risk assessment of heavy metal in the sediment of Turag river, Bangladesh: An index analysis approach. J. Water Resource Prot., 5: 239-248. DOI: $10.4236 /$ jwarp.2013.52024

Barakat, A., M.E. Baghdadi, J. Rais and S. Nadem, 2012. Assessment of heavy metal in surface sediments of Day river at Beni-Mellal Region, Morocco. Res. J. Environ. Earth Sci., 4: 797-806.

Bharti, P.K. and V. Singh, 2013. Heavy metals distribution in sediment and water of Phrinkaruh river in East Khasi Hills, Meghalaya. Int. J. Higher Educ. Res., 2: 55-63.

Bhuiyan, M.A.H., S.B. Dampare, M.A. Islam and S. Suzuki, 2015. Source apportionment and pollution evaluation of heavy metals in water and sediments of Buriganga river, Bangladesh, using multivariate analysis and pollution evaluation indices. Environ. Monit. Assess., 187: 4075-4075.

DOI: $10.1007 / \mathrm{s} 10661-014-4075-0$

CCME, 1999. Canadian water quality guidelines for protection of aquatic life. Canadian Water Quality Index 1.0, Technical Report, Canadian Environmental Quality Guidelines.
Datta, D.K. and V. Subramanian, 1998. Distribution and fraction of heavy metals in the surface sediments of the Ganges-Brahmaputra-Meghna river system in the Bengal Basin. Environ. Geol., 36: 93-101. DOI: $10.1007 / \mathrm{s} 002540050324$

DoE, 1997. Environment conservation rules, E.C.Rschedule 3, standards for water. Department of Environment of Bangladesh.

El-Sammak, A.A. and T.A. Abdul-Kassim, 1999. Metal pollution in the sediments of Alexandria Region, Southern Mediterranean, Egypt. Bull. Environ. Contam. Toxicol., 63: 263-270. DOI: $10.1007 / \mathrm{s} 001289900975$

Farkas, A., C. Erratico and L. Vigano, 2007. Assessment of the environmental significance of heavy metal pollution in surficial sediments of the river Po. Chemosphere, 68: 761-768.

DOI: $10.1016 /$ j.chemosphere.2006.12.099

Hakanson, L., 1980. An ecological risk index for aquatic pollution control a sedimentological approaches. Water Res., 14: 975-1001. DOI: 10.1016/0043-1354(80)90143-8

Harikumar, P.S., U.P. Nasir and R.M.P. Mujeebu, 2009. Distribution of heavy metals in the core sediments of a tropical wetland system. Int. J. Environ. Sci. Tech., 6: 225-232. DOI: 10.1007/BF03327626

Hasan, I., S. Rajia, K.A. Kabir and G.A. Latifa, 2009. Comparative study on the water quality parameters in two rural and urban rivers emphasizing on the pollution level. Global J. Environ. Res., 3: 218-222.

Huq, S.M.I. and M. Didar-ul-Alam, 2005. A Handbook on Analyses of Soil, Plant and Water. 1st Edn., Momin Offset Press, Dhaka, Bangladesh.

Islam, M.S., M.K. Ahmed, M. Raknuzzaman, M. Habibullah-Al-Mamun and M.K. Islam, 2015. Heavy metal pollution in surface water and sediment: A preliminary assessment of an urban river in a developing country. Ecol. Indicators, 48: 282-291. DOI: 10.1016/j.ecolind.2014.08.016

Islam, M.M., S.L. Rahman, S.U. Ahmed and M.K.I. Haque, 2014. Biochemical characteristics and accumulation of heavy metals in fishes, water and sediments of the river Burigonga and Shitalakhya of Bangladesh. J. Asian Sci. Res., 4: 270-279.

Islam, M.S., N.T. Meghla, Suravi, S.A. Mamun and M. Islam, 2012. Status of water quality in the Dhaleshwari river and its effect on aquatic organism. J. Environ. Sci. Water Resourc., 1: 192-201.

Loska, K., D. Wiechula, B. Barska, E. Cebula and A. Chojnecka, 2003. Assessment of Arsenic enrichment of cultivated soils in Southern Poland. J. Environ. Stud., 2: 187-192.

Jumbe, A.S. and N. Nandini, 2009. Heavy metals analysis and sediment quality values in urban lakes. Am. J. Environ. Sci., 5: 678-687. DOI: 10.3844/ajessp.2009.678.687 
Kura, B., K. Kambham, S. Sangameswaran and S. Potana, 2006. Atmospheric particulate emissions from dry abrasive blasting using coal slag. J. Air Waste Manag. Assoc., 56: 1206-1215. DOI: $10.1080 / 10473289.2006 .10464533$

Manoj, K., B. Kumar and P.K. Padhy, 2012. Characterisation of metals in water and sediments of Subarnarekha river along the projects' sites in Lower Basin, India. Universal J. Environ. Res. Technol., 2: 402-410.

Mirza, M.Q., R.A. Warrick, N.J. Ericksen and G.J. Kenny, 1998. Trends and persistence in precipitation in the Ganges, Brahmaputra and Meghna river basins. Hydrol. Sci. J., 43: 845-858.

DOI: $10.1080 / 02626669809492182$

Mohiuddin, K.M., Y. Ogawa, H.M. Zakir, K. Otomo and N. Shikazono, 2011. Heavy metals contamination in water and sediments of an Urban river in a developing country. Int. J. Environ. Sci. Tech., 8: 723-736. DOI: 10.1007/BF03326257

Mohiuddin, K.M., H.M. Zakir, K. Otomo, S. Sharmin and N. Shikazono, 2010. Geochemical distribution of trace metal pollutants in water and sediments of downstream of an urban river. Int. J. Environ. Sci. Tech., 7: 17-28. DOI: $10.1007 / \mathrm{BF} 03326113$

Mokaddes, M.A.A., B.S. Nahar and M.A. Baten, 2013. Status of heavy metals contamination of river water of Dhaka metropolitan city. J. Environ. Sci. Nat. Resources, 5: 349-353.

Moore, F., G. Forghani and A. Qishlaqi, 2009. Assessment of Heavy Metal Contamination in Water and Surface Sediments of the Maharlu Saline Lake, SW Iran. Iran J. Sci. Technol., 33: 43-55.

Müller, G., 1969. Index of geoaccumulation in sediments of the Rhine river. Geol. J., 2:109-118.

Müller, G., 1981. The heavy metal pollution of the sediments of Neckars and its tributary. Chemiker Zeitung, 105: 157-164.

Ogbeibu, A.E., M.O. Omoigberale, M.I. Ezenwa, J.O. Eziza and J.O. Igwe, 2014. Using pollution load index and geoaccumulation index for the assessment of heavy metal pollution and sediment quality of the Benin river, Nigeria. Nat. Environ., 2: 1-9. DOI: $10.12966 /$ ne.05.01.2014

Qingjie, G. and D. Jun, 2008. Calculating pollution indices by heavy metals in ecological geochemistry assessment and a case study in parks of Beijing. J. China Univ. Geosci., 19: 230-241. DOI: $10.1016 / \mathrm{S} 1002-0705(08) 60042-4$

OSHA, 2006. Abrasive blasting bazards in shipyard employment. United States Occupational Safety and Health Administration.
Rabee, A.M., Y.F. Al-Fatlawy, A.N. Abdown and M. Nameer, 2011. Using Pollution Load Index (PLI) and geoaccumulation index (I-Geo) for the assessment of heavy metals pollution in Tigris river sediment in Baghdad region. J. Al-Nahrain Univ., 14: 108-114.

Rahman, M.A. and M.E. Huda, 2012. Study of the seasonal variations in physicochemical and biological aspects of the Padma river at Paturia Ghat, Manikgonj. Jahangirnagar Univ. Environ. Bull., 1: 55-66. DOI: 10.3329/jueb.v1i0.14548

Rahman, M.N., 2013. IWRM of Ganges-BrahmaputraMeghna basin. Proceedings of the 8th NARBO IWRM Training, Nov. 27-Dec. 4, Sri Lanka.

Rahman, M.S., N. Saha and A.H. Molla, 2014. Potential ecological risk assessment of heavy metal contamination in sediment and water body around Dhaka export processing zone, Bangladesh. Environ. Earth Sci., 71: 2293-2308. DOI: $10.1007 / \mathrm{s} 12665-013-2631-5$

Rashid, H., M.N. Hasan, M.B. Tanu, R. Parveen and Z.P. Sukhan et al., 2012. Heavy metal pollution and chemical profile of Khiru river, Bangladesh. Int. J. Environ., 2: 57-63.

Saha, P.K. and M.D. Hossain, 2011. Assessment of heavy metal contamination and sediment quality in the Buriganga river, Bangladesh. Proceedings of the 2nd International Conference on Environmental Science and Technology, (EST' 11), IACSIT Press, Singapore, pp: 384-388.

Sikder, M.T., Y. Kihara, M. Yasuda, Yustiawati and Y. Mihara et al., 2013. river water pollution in developed and developing countries: Judge and assessment of physicochemical characteristics and selected dissolved metal concentration. Clean Soil Air Water, 41: 60-68. DOI: 10.1002/clen.201100320

Silambarasan, K., V. Senthilkumaar and K. Velmurugan, 2012. Studies on the distribution of heavy metal concentrations in river Adyar, Chennai, Tamil Nadu. Eur. J. Exp. Biol., 2: 2192-2198.

Singh, L., S.K. Choudhary and P.K. Singh, 2012. Status of heavy metal concentration in water and sediment of river Ganga at selected sites in the middle Ganga plain. Int. J. Res. Chem. Environ., 2: 236-243.

Suthar, S., A.K. Nema, M. Chabukdhara and S.K. Gupta, 2009. Assessment of metals in water and sediments of Hindon river, India: Impact of Industrial and Urban Discharges. J. Hazard. Mater., 171: 1088-1095. DOI: 10.1016/j.jhazmat.2009.06.109

Tareq, S.M., M.S. Rahman, S.Y. Rikta, S.M.N. Islam and M.S. Sultana, 2013. Seasonal variation in water quality of the Ganges and Brahmaputra river, Bangladesh. Jahangirnagar Univ. Environ. Bull., 2: 71-82. DOI: $10.3329 /$ jueb.v2i0.16332 
Tomlinson, D.L., J.G. Wilson, C.R. Harris and D.W. Jeffney, 1980. Problems in the assessment of heavymetal levels in estuaries and the formation of a pollution index. Helgol. Meeresunters., 33: 566-572. DOI: $10.1007 / \mathrm{BF} 02414780$

Turekian, K.K. and K.H. Wedepohl, 1961. Distribution of the elements in some major units of the earth's crust. Am. Geol. Soc. Bull., 72: 175-192. DOI: $10.1130 / 0016-$ 7606(1961)72[175:DOTEIS]2.0.CO;2

Uddin, M.M., M. Zafar and S.R. Chowdury, 2014. Water, salt and nutrient flux through the lower Meghna river estuary, Bangladesh. Indian J. Mar. Sci., 43: 280-283.

USEPA, 1989. Sediment classification methods compendium. Draft Final Report, United States Environmental Protection Agency, Watershed Protection Division, USA.

USEPA, 1999. Screening level ecological risk assessment protocol for hazardous waste combustion facilities, Appendix E: Toxicity reference values. United States Environmental Protection Agency.
USEPA, 2008. National primary drinking water standards. United States Environmental Protection Agency.

Varol, M., 2011. Assessment of heavy metal contamination in sediments of the Tigris river (Turkey) using pollution indices and multivariate statistical techniques. J. Hazard. Mater., 195: 355-364. DOI: 10.1016/j.jhazmat.2011.08.051

Walkley, A. and I.A. Black, 1934. An examination of Degtjareff method for determining Soil organic matter and a proposed modification of the chromic acid titration method. Soil Sci., 37: 29-37. DOI: 10.1097/00010694-193401000-00003

WHO, 1993. Guidelines for drinking water quality. World Health Organization, Geneva, Switzerland.

WHO, 2004. Guidelines for Drinking Water Quality. 3rd Edn., World Health Organization, pp: 515.

Yaqin, J., F. Yinchang, W. Jianhui, Z. Tan and B. Zhipeng and D. Chiqing, 2008. Using geoaccumulation index to study source profiles of soil dust in China. J. Environ. Sci., 20: 571-578. 